\title{
Revisiting the Didactic Triangle in the Case of an Adaptive Learning System
}

\author{
http://dx.doi.org/10.3991/ijep.v4i4.3891 \\ Yassine Zaoui Seghroucheni ${ }^{1}$, Mohammed Al Achhab ${ }^{2}$ and Badr Eddin El Mohajir ${ }^{1}$ \\ ${ }^{1}$ Faculty of Sciences, Tetouan, Morocco \\ 2 The National School of Applied Sciences, Tetouan, Morocco
}

\begin{abstract}
-in this paper we revisit the classical approach of the didactic triangle designed for the classical learning situation (face to face) and adapt it to the situation of an adaptive learning system, we discuss also the different components involved in this didactic triangle and how they interact and influence the learning process in an adaptive learning system.
\end{abstract}

Index Terms-Adaptive Learning system, Didactic Triangle, pedagogy, Didactic tetrahedron

\section{INTRODUCTION}

The use of Internet for educational purposes continues to transform learner's habits in terms of knowledge acquisition. Thus it is very essential to delineate the different components involved in this process in order to better understand the relationships linking the various components in the e-learning system. For the classical learning situations (face to face), the didactic triangle introduced by Houssaye [2] defines the relationships in any learning situation, of course this theory certainly does not become obsolete by any means and at the same time, the relationships defined in the didactic triangle are not automatically effectives in a learning situation remotely via an elearning platform, since the role of the teacher is very limited on one hand, and the appearance of the e-learning platform requires rethinking the whole process.

For instance, the authors of [10] introduced a didactical tetrahedron as a heuristic for analyzing the incorporation of digital technologies into classroom practice in support of investigate approaches to teaching mathematics, they make a technological dimension visible. Kenneth Ruthven [10] suggests that the didactical triangle is a heuristic that identifies what are taken to be the fundamental components of any didactic system: teacher, student and content. Naturally, amongst these three components, subjectspecific didactics gives particular attention to analyzing subject content with the aim of developing an effective presentation and sequencing of such content for the purposes of teaching and learning.

The educational use of Internet clearly relates to the concerns of the didactical triangle, and the relations and interactions between its components. Consequently, there have been several proposals [22], [29] to expand the triangle by the addition of a fourth vertex to create a didactical tetrahedron that makes the significance of technology explicit. However to the best of our knowledge, none of this works have been able to revisit the didactic triangle in the case of an adaptive learning system. Therefore our aim is to explore the didactic triangle and project the effective components to the case of an adaptive learning system.

Throughout this paper we try to redefine the didactic triangle for the case of an adaptive learning system, with all the requirements and advantages that these systems bring into the mix. The rest of this paper is organized as follow:

In section 2, we present a state of the art of the different works that have treated the subject of pedagogy in elearning. Section 3 will be devoted to an overview of the connectivism, while in section 4 we will be discussing the particularities of the adaptive learning systems, and especially defining the parameters involved in the adaptation of the content into learners' profiles, then in section 5 we will recall the classical didactic triangle. Later in section 6 we will introduce the new didactic triangle revisited and redefined to the situation of an adaptive learning system and discuss its new outcomes. Finally some conclusions are drawn in section 7 .

\section{RELATED WORK}

Long before the hype around the adaptive learning systems becomes more pronounced, many authors questioned whether the e-learning requires new pedagogies or not [1], [3], [4]. In [5] the author puts e-learning into perspectives and discusses mainly the new theory of connectivism introduced by [6]. Downes [7] States that online course offering should move away from large, centralized applications and instead make a use of a network of connected applications, "Connectivism \& connective knowledge is not simply about the use of networks of diverse technologies; it's a network of diverse technologies".

More efforts were drawn into the didactic triangle [2] to determine the ins and outs of the pedagogical situation in an e-learning system, for example in [8] the authors structure and analyze research on the teaching and learning of programming, they argue that more focus should be done on the edges of the triangle, while [9] suggests that the typical framing of the didactic triangle is narrower than it should be, and it should be broadened to view classroom activities from a more social / cultural point of view.

\section{OVERVIEW ON THE CONNECTIVISM}

An e-pedagogy already exists, and it relays on the new approach called the connectivism. According to Siemens [6]: "connectivism is driven by the understanding that decisions are based on rapidly altering foundations. New information is continually being acquired and the ability to draw distinctions between important and unimportant information is vital. Also critical is the ability to recognize 
PAPER

REVISITING THE DidACTIC TRIANGLE IN THE CASE OF AN ADAPTIVE LEARNING SYSTEM

TABLE I.

A COMPARISON BETWEEN THE DIFFERENT PEDAGOGIES

\begin{tabular}{|c|c|c|c|c|}
\hline Questions & Behaviorism & Cognitivism & Constructivism & Connectivism \\
\hline $\begin{array}{l}\text { How does learning } \\
\text { occur? }\end{array}$ & $\begin{array}{l}\text { Black box - observable } \\
\text { behavior main focus }\end{array}$ & Structured, computational & Social, created by each learner & $\begin{array}{l}\text { Distributed within a network, } \\
\text { social, technologically en- } \\
\text { hanced, }\end{array}$ \\
\hline $\begin{array}{l}\text { What factors influence } \\
\text { learning? }\end{array}$ & $\begin{array}{l}\text { Nature of reward, punish- } \\
\text { ment }\end{array}$ & $\begin{array}{l}\text { Existing schema, previous } \\
\text { experiences }\end{array}$ & $\begin{array}{l}\text { Engagement participation, } \\
\text { social, cultural }\end{array}$ & Diversity of networks \\
\hline $\begin{array}{l}\text { What is the role of the } \\
\text { memory }\end{array}$ & $\begin{array}{l}\text { Memory is hardwiring of } \\
\text { repeated experiences } \\
\text { where reward and punish- } \\
\text { ment are most influential }\end{array}$ & Encoding, storage retrieval & $\begin{array}{l}\text { Prior knowledge remixed to } \\
\text { current context }\end{array}$ & $\begin{array}{l}\text { Adaptive patterns, representa- } \\
\text { tive of current state, existing } \\
\text { in networks }\end{array}$ \\
\hline $\begin{array}{l}\text { How does transfer } \\
\text { occur? }\end{array}$ & Stimulus, response & $\begin{array}{l}\text { Duplicating knowledge } \\
\text { constructs of "knower" }\end{array}$ & Socialization & Connecting to (adding nodes) \\
\hline $\begin{array}{l}\text { What types of learn- } \\
\text { ing are best explained } \\
\text { by this theory }\end{array}$ & Task-based learning & $\begin{array}{l}\text { Reasoning, clear objectives, } \\
\text { problem solving }\end{array}$ & Social & $\begin{array}{l}\text { Complex learning, rapid } \\
\text { changing core, diverse } \\
\text { knowledge sources }\end{array}$ \\
\hline
\end{tabular}

when new information alters the landscape based on decisions made yesterday".

\section{A. Principals of Connectivism}

Based on the above definition, Siemens [6] posits the following principles of connectivism:

- Learning and knowledge rest in diversity of opinions.

- Learning is a process of connecting specialized nodes or information sources.

- Learning may reside in non-human appliances. Capacity to know more is more critical than what is currently known.

- Nurturing and maintaining connections is needed to

- facilitate continual learning.

- Ability to see connections between fields, ideas, and concepts is a core skill.

\section{B. A comparison between the connectivism and the classical approaches of learning}

How does connectivism compare to other learning theories? How does it differ from established paradigms? Table I illustrates both the similarities and differences between connectivism and the three major philosophical perspectives on learning.

\section{The ADAPTIVE LEARNING SySTEMS}

An adaptive learning system (ALS) is a learning Management System (LMS) that, quite simply, can adapt to the needs of the learner. Unlike a traditional LMS, which acts as a repository of information and a tool for the training administrator to assign modules and track progress, an ALS assigns modules based on learner needs/styles/competence level/etc. And sometimes it has the ability to assess learner progress and account for this while creating the learning path.

There are several approaches that fall into the direction of personalizing learning path and offering an adapted content to the learner profiles, those works can be summarized into two categories:

The first category contains systems who tend to use implicit methods for identifying learning styles based mainly on the analysis [11], [12] and observation [13], [14] of the learners behaviors in the system, however those methods are not completely reliable given the fact that the learners can engage in other activities during learning. The second category contains the content adaptation systems that use explicit methods for identifying learning styles by using e-questionnaires [15], [16], [17] or letting the learners express their preferences [18] personal characteristics [19] or using the FSLSM [20], [21].

\section{A. Requirements of Adaptive Learning Systems}

In [24] the authors have come to the conclusion that the adaptation within an adaptive learning system is done while taking into consideration certain parameters notably the learning style and the versioning of the different Learning Objects. In fact those learning objects are designed according to the needs, competences and prerequisites of learners.

Figure 2 summarizes the essential components of the ALS systems.

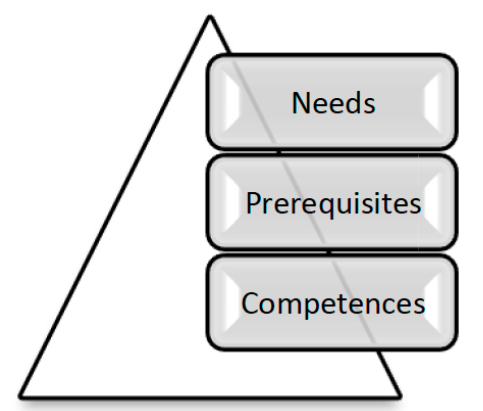

Figure 1. The adaptation in Learning Objects

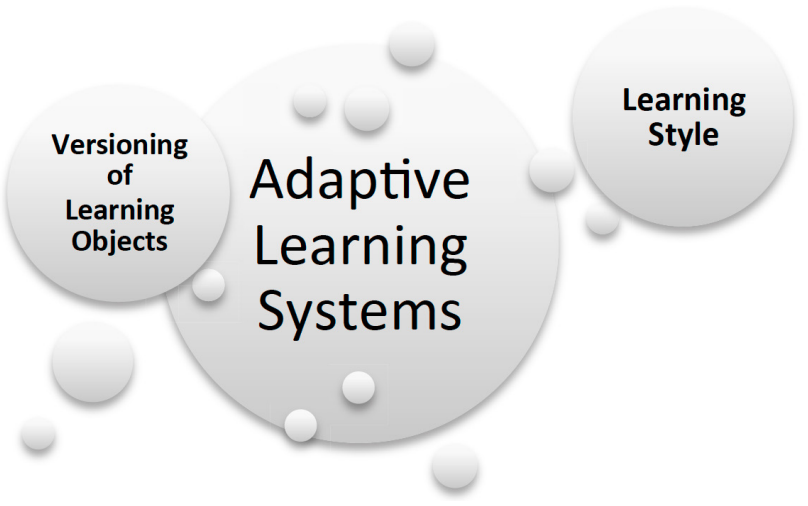

Figure 2. The adaptation in an ALS 


\section{THE DidACTIC TRIANGLE}

The pedagogical triangle [2] is a system of explanatory reference, which bases the relationship between three areas: learners, teachers and knowledge. It is a reflexive support for pedagogical situations where the learner is face to face with the teacher in the same place and at the same time (Figure 3).

This triangle is essentially based on three pedagogic relations:

The learning process relation: it shows the direct relationship between Learner- knowledge. This relationship is favored and the teacher is the organizer of external learning processes. He is a mediator and there is a stronger bond between the learner and knowledge.

The teaching process relation: the relationship privileged here is the teacher-knowledge relationship. The teacher structures lessons for the learner. He looks for the content.

The training process relation: this relation is centered on the relation teacher-learner. They are constantly in interaction. The teacher presents situations for the learner to resolve and when the learner can't he turns to the teacher for remediation.

When the components of the didactic triangle are remote, this representation has its limits, because some elements become more important while they weren't necessarily before. The educational use of technologies, then, clearly relates to the concerns of the didactical triangle and the relations and interactions between its components. Consequently, there have been several proposals to expand the triangle by the addition of a fourth vertex to create a didactical tetrahedron that makes the significance of technology explicit. The didactic triangle has been revisited already in the works of [10], [22] to take into consideration a fourth vertex which is the E-Learning.

\section{A. The didactic tetrahedron}

Lombard [22] considers that Houssaye's didactic triangle should take a new dimension and become a tetrahedron under the influence of ICT. He emphasizes the fact that ICT enriches the educational situation by a fourth vertex of interaction. He thus proposes to develop a 3D pedagogical triangle to take into account a new variable of paramount importance: we have therefore an educational technology tetrahedron for ICT integration. From this design, Lombard develops the idea of a tetrahedron, placing ICT as the fourth vertex, called "cyberprof device" (Figure 4).

This tetrahedron is used to analyze the interactions between the components of the pedagogical relationship: teacher-student-knowledge and cyberprof device. It consists of four triangular faces and six edges ABCDEF. In fact [22] states that "This is a tool to dissect and explain the circulation between the poles of the educational situation in the activity to highlight its contradictions, illuminate its inconsistencies or illustrate the fruitful paths". However this transformation is narrow in the case of an adaptive learning system, given the fact that it does not emphasize the new parameters that emerge in the case of an adaptive learning.

\section{The ALS Didactic TRIANGLE}

The didactic triangle is a frequently used tool way long before the appearance of e-learning, to analyze scenarios and also the functions and dysfunctions of learning situations. However the didactic triangle as presented in the works of [22], [23] does not take into consideration the new specifics of the new learning situations brought by the adaptive learning systems, which are mainly the learning style and the possibility of creating multiple versions (versioning) of the same learning objects [24]. What we propose is to extend the didactic triangle to a tetrahedron by editing the fourth vertex of [10], [22]. Having said that, the classical didactic triangle becomes as we show in Figure 5.

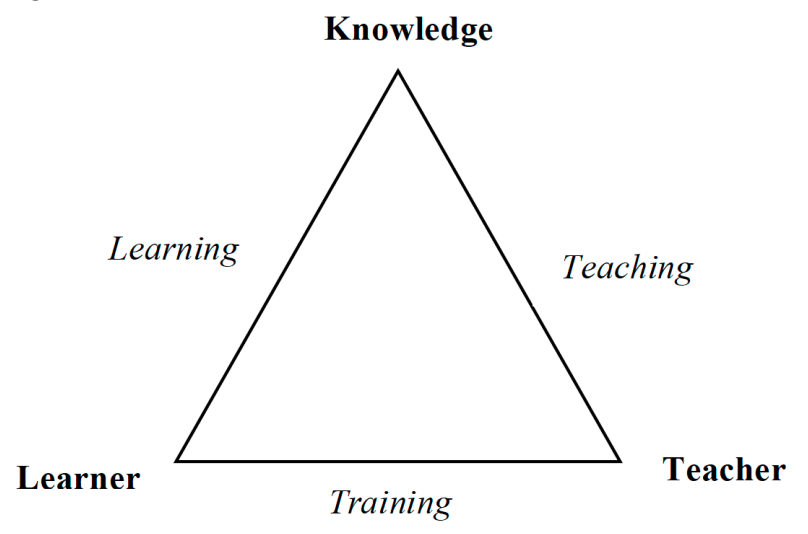

Figure 3. The Didactic Triangle of HOUSSAYE

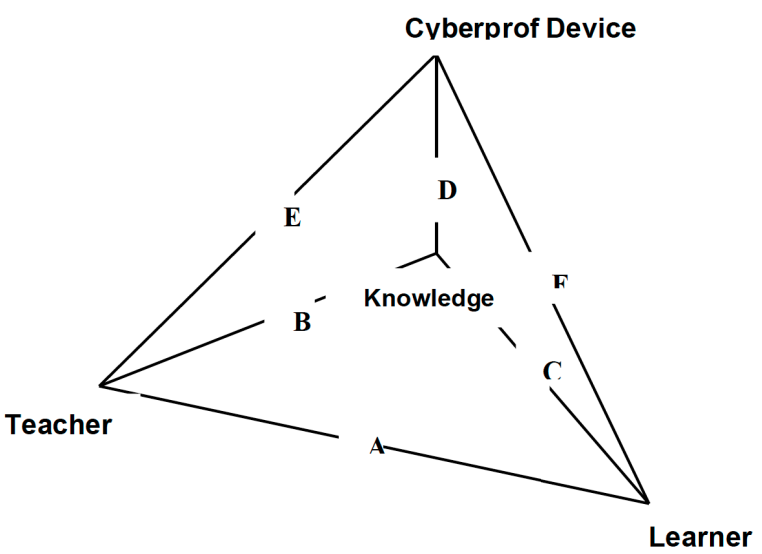

Figure 4. The didactic tetrahedron of Lombard

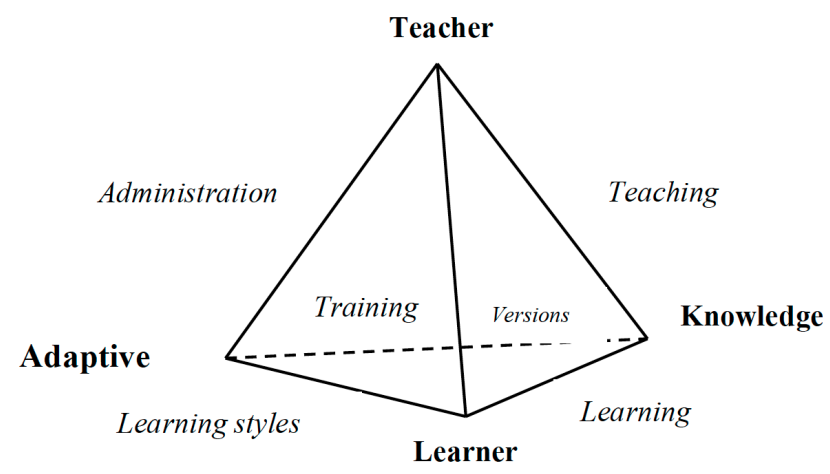

Figure 5. The ALS Didactic Tetrahedron 


\section{A. Analysis of the Dynamics of the ALS tetrahedron}

The tetrahedron is obviously made up of four surfaces; each surface will be analyzed separately:

- Triangle $\mathrm{N}^{\circ}$ 1: The classical triangle of HOUSSAYE, having as vertices; Learner-Teacher-Knowledge (LT-K)

- Triangle $\mathrm{N}^{\circ}$ 2: The (Teacher-Learner-Adaptive L earning System) Triangle having as vertices (T-LALS)

- Triangle $\mathrm{N}^{\circ}$ 3: The (Teacher-Knowledge-Adaptive Learning System) Triangle having as vertices (T-KALS)

- Triangle $\mathrm{N}^{\circ}$ 4: The (Learner-Knowledge-Adaptive Learning System) Triangle having as vertices (L-KALS)

The triangles that represent our cases of interest are: the (T-L-ALS) Triangle, the (T-K-ALS) Triangle and the (LK-ALS) Triangle as the triangle $\mathrm{N}^{\circ} 1$ is the didactic triangle already developed in section 5 .

\section{B. The Teacher-Learner-Adaptive Learning System Triangle ( $T-L-A L S)$}

The surface of the tetrahedron containing the vertices: Teacher; Learner and ALS, forms the triangle called (T-LALS) triangle (Figure 6), while the fourth vertex of the tetrahedron is deactivated in this case, in fact as JEAN HOUSSAYE [2] wrote in "La Pédagogie, une encyclopédie pour aujourd'hui" : "The educational situation can be defined as a triangle made up of three elements, knowledge, the teacher and students, two of which are formed as subject, while the third one must accept the place of dead, or, failing that, to get mad". Obviously the vertex called Knowledge is not significant at this presentation which is adequate to what suggest Houssaye [2].

The watchword in this area is learning style. The adaptation is done according to the learning styles; this adaptation is administrated by the teacher, who becomes more involved in the platform and sees his role and tasks evolve in the system. In fact the learning process takes place according to the learning style of each learner, There are several models of learning styles in the literature such David A. Kolb [26], Honey and Mumford [27] and Felder and Silverman [28], each with different descriptions and classifications of types of learning.

\section{The Teacher-Knowledge-Adaptive Learning System Triangle (T-K-ALS)}

As we explained in the subsection above, each time a fourth vertex is absent and in this case it is the learner.

The adaptation in this triangle (Figure 7) is done according to what recommend the authors of [24], in fact creating multiple versions of the same learning object is extremely important in an ALS, this aligns also with what PHILIPPE MEREUI [25] suggests in the differentiated pedagogy.

\section{The Knowledge-Learner-Adaptive Learning System Triangle (K-L-ALS)}

This triangle illustrates the relationship between the vertices: Learner, Knowledge and ALS.
As shown in Figure 8, the vertices named; Knowledge, Learner and ALS compose the $K-L-A L S$ Triangle which is the basis of the tetrahedron; this triangle represents the core of the learning situation in the case of an adaptive learning system as it highlights the main components characterizing the interactions in an ALS, the teacher in this triangle steps aside in the benefits of the requirement of the learning situation.

In Table II we summarize the relationships between all the vertices in the different triangles.

It shows that the K-L-ALS triangle is where the most aspects of adaptation are located, which is totally logic as it represents the basis or even the core of the tetrahedron.

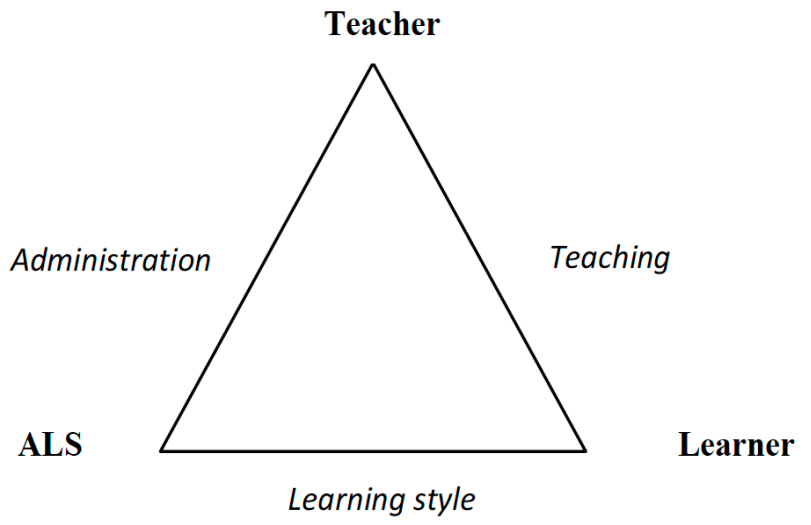

Figure 6. The (T-L-ALS) Triangle

Teacher

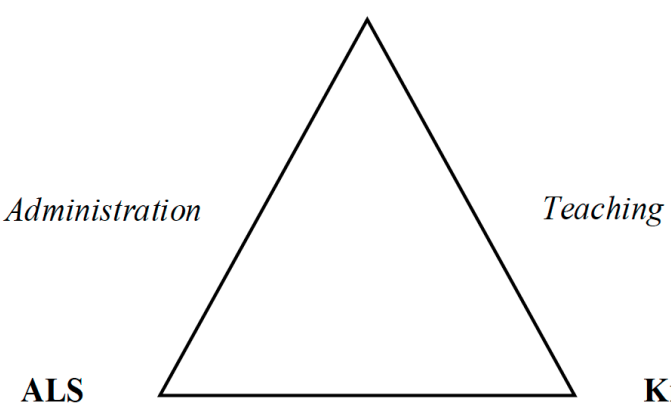

Knowledge

Versions

Figure 7. The (T-K-ALS) Triangle

Knowledge

ALS

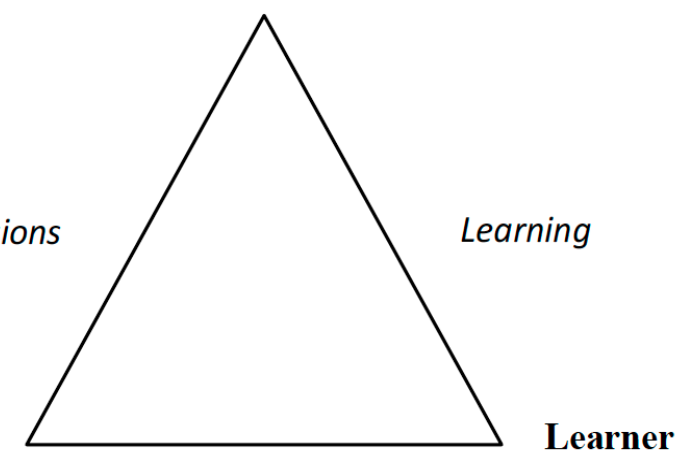

Learning Style

Figure 8. The (K-L-ALS) Triangle 
TABLE II.

A RECAP OF THE RELATIONSHIPS INSIDE THE ALS TETRAHEDRON

\begin{tabular}{|c|c|c|}
\hline Triangle & Edges & Relations \\
\hline \multirow{3}{*}{ K-L-ALS } & ALS-Learner & $\begin{array}{l}\text { This relationship is based on detecting learning styles (im- } \\
\text { plicitly or explicitly) }\end{array}$ \\
\hline & ALS-Knowledge & $\begin{array}{l}\text { This relationship is based on Learning objects; in fact the } \\
\text { ALS provides the adequate LO according to the need, } \\
\text { prerequisites and competence of the learner. }\end{array}$ \\
\hline & Knowledge-Learner & $\begin{array}{l}\text { This is the most important relationship in the learning } \\
\text { situation; the system is based around this relationship. The } \\
\text { ALS represents a mediator who provides the necessary } \\
\text { tools to sustain this relation. }\end{array}$ \\
\hline \multirow{3}{*}{ T-K-ALS } & Teacher-Knowledge & $\begin{array}{l}\text { The teacher designs the learning objects and creates multi- } \\
\text { ple versions of the same learning objects. }\end{array}$ \\
\hline & Teacher-ALS & $\begin{array}{l}\text { This relationship forces a change in the role of the teacher; } \\
\text { in fact his role evolves and includes the administration of } \\
\text { the system. }\end{array}$ \\
\hline & Knowledge-ALS & $\begin{array}{l}\text { In this triangle, this relationship is based on the versioning } \\
\text { of learning objects and it is supervised by the Teacher. }\end{array}$ \\
\hline \multirow{3}{*}{ T-L-ALS } & Teacher-Learner & $\begin{array}{l}\text { This relationship in the system is the weakest link as the } \\
\text { learning is done through the system. }\end{array}$ \\
\hline & Teacher-ALS & $\begin{array}{l}\text { This relationship consists at the administration of the sys- } \\
\text { tem and in the presence of the learner as the third vertex; } \\
\text { this administration may include also tracking different } \\
\text { informations about the learners. }\end{array}$ \\
\hline & Learner-ALS & $\begin{array}{l}\text { This relationship is based on the learning style which can } \\
\text { be detected as the learner advance in learning or expressed } \\
\text { explicitly via e-questionnaire, etc... }\end{array}$ \\
\hline
\end{tabular}

\section{CONCLUSION}

Through this paper we presented a didactic tetrahedron which is valid for the case of an adaptive learning system, we edited the 3D tetrahedron and adapted it to the case of an adaptive learning system. The analysis by the tetrahedron helps us to dissect the adaptive learning systems and understand the ins and outs of these platforms; it also allows apprehending the relationships between the different components within those systems.

\section{REFERENCES}

[1] Bobby Elliott, e-pedagogy, does e-learning requires a new approach to teaching and learning? Scottish qualifications authority, January 2009.

[2] Jean Houssaye, le triangle didactique, 1988-1992.

[3] Wassila Naamani Mehanna, e-Pedagogy: the pedagogies of elearning, University of Cambridge, UK, ALT-J, Research in Learning Technology Vol. 12, No. 3, September 2004.

[4] Gráinne Conole Review of pedagogical models and their use in elearning,g.c.conole@open.ac.uk, 2010

[5] Clarissa Davis, Earl Edmunds, Vivian Kelly-Bateman, Connectivism, From Emerging Perspectives on Learning, Teaching and Technology, Department of Educational Psychology and Instructional Technology, University of Georgia, 2012

[6] George Siemens, Connectivism: A Learning Theory for the Digital Age, www.connectivism.ca, December 12, 2004

[7] Stephen Downes, Places to Go: Connectivism \& Connective Knowledge September 29, 2008.

[8] Anders Berglund and al, Introductory Programming and the Didactic Triangle, Proc. 12th Australasian Computing Education Conference (ACE 2010), Brisbane, Australia

[9] Alan H. Schoenfeld, Problematizing the didactic triangle, ZDM Mathematic Education, 19 March 2012,

[10] Kenneth Ruthven, The didactical tetrahedron as a heuristic for analysing the incorporation of digital technologies into classroom practice in support of investigative approaches to teaching mathematics, ZDM, 2012
[11] Vincenza Carchiolo and Alessandro Longheu and Michele Malgeri and Giuseppe Mangioni, An Architecture to Support Adaptive E-Learning, IJCSNS International Journal of Computer Science and Network Security, VOL.7 No.1, January 2007.

[12] Nabila Bousbia, Issam Reba, Jean-Marc Labat, Amar Balla, Analyzing the record Relationship between Learning Styles and Navigation Behavior in Web-Based Educational System, Knowledge Management ELearning: An International Journal, Vol.2, No.4. 400

[13] Silvia Schiaffino , Patricio Garcia, Analia Amandi, E-teacher providing personalized assistance to e-learning students? SISTAN Research Institute Fac. Cs. Exactas - UNCPBA, Campus Universitario, Paraje Arroyo Seco, 7000 Tandil, Buenos Aires, Argentina, 2008.

[14] Sabine Graf and Kinshuk Providing Adaptive Courses in Learning Management Systems with Respect to Learning Styles, Vienna University of Technology Women's Postgraduate College for Internet Technologies Vienna, Austria Athabasca.

[15] Paraskevi Tzouveli Phivos Mylonas, Stefanos Kollias, An intelligent e-learning system based on learner profiling and learning resources adaptation,National Technical University of Athens, School of Electrical and Computer Engineering, Athens, Greece Received 7 February 2007; received in revised form 4 May 2007; accepted 4 May 2007.

[16] Boyan Bontchev and Dessislava Vassileva Courseware Adaptation to learning styles and knowledge level, Department of Software Engineering, Sofia University, Sofia Bulgaria.

[17] Sabone Graf, Silvia Rita Viola,Tommaso Leo and Kinshuk InDepth Analysis of the Felder-Silverman Learning Style Dimensions, Journal of Research on Technology in Education, 2007, 40(1). http://dx.doi.org/10.1080/15391523.2007.10782498

[18] Ana-Elena Guerrero-Roldn , Juli Minguilln Alfonso Adaptive learning paths for Improving lifelong learning experiences? Department of Computer Science, Universitat Oberta de Catalunya, Barcelona, Spain.

[19] Stphanie Jean-Daubias, Thi-Thu-Hong Phan, Different levels of modeling for learner profiles,

[20] Felder, R. M., Silverman , L. K. (1988), Learning and Teaching Styles in Engineering Education Education. Engineering, 78 (7). Preceded by a preface in 2002. 
[21] Papanikolaou , KA , Grigoriadou , M., Kornilakis , H., Magoulas , GD (2003) Personalizing the interaction in a Web-based educational hypermedia system : the case of INSPIRE . User- Modeling and User -Adapted Interaction, 13, pp . 213-267.

[22] François Lombard, Université de Genève TECFA, Chapitre 8. Du triangle de Houssaye au tétraèdre des TIC : comprendre les interactions entre les savoirs d'expérience et ceux de recherche Transformations des regards sur la recherche en Technologie de l'Education Bernadette Charlier, Daniel Peraya, 2003.

[23] Jackdub, Quelle place pour le groupe dans le triangle pédagogique ?, 16 octobre 2012, http://prodageo.wordpress.com/2012/ 10/16/quelle-place-pour-le-groupe-dans-le-triangle-pedagogique/

[24] Exploitation of the recommendation systems in the calculation of the learning path, Forthcoming ICICS, The fifth international Conference on information and communication systems, April 1-3, 2014, Ibrid Jordan

[25] Philippe Meiriu, Apprendre... oui, mais comment?, ESF éditeur, Paris, $1987,17^{\circ}$ edition, 1999.

[26] David Kolb, Experiential learning: experience as the source of learning and development 1984.

[27] Honey and Mumford, Using Your Learning Styles - second edition, Peter Honey, Maidenhead, 1986.
[28] Felder, R. M., Silverman, L. K. (1988), Learning and Teaching Styles in Engineering Education Education. Engineering, 78 (7). Preceded by a preface in 2002.

[29] Faerber, R. (2002). Le groupe d'apprentissage en formation à distance : ses caractéristiques dans un environnement virtuel. In Larose F \& Karsenti T. (Ed.), La place des TICE en formation initiale et continue à l'enseignement : bilan et perspectives. Sherbrooke: Éditions du CRP, Université de Sherbrooke, 99-128.

\section{AUTHORS}

Yassine Zaoui Seghroucheni is with the Faculty of Sciences, Tetouan (e-mail: yassinezaouiseghroucheni@gmail.com).

Mohammed Al Achhab is with the National School of Applied Sciences, Tetouan (e-mail: alachhab@gmail.com).

Badr Eddin El mohajir is with the faculty of Sciences, Tetouan (email: b.elmohajir@ieee.ma)

Submitted 15 May 2014. Published as resubmitted by the authors 05 October 2014. 